\title{
Policy for Implementing Housing Development Licensing for Low-Income Communities in Palembang City
}

\author{
Zanariah$^{1}$, Irfan Ridwan Maksum², Eko Prasodjo ${ }^{3}$ \\ 1,2,3 University of Indonesia \\ Email: zanariah69@yahoo.com
}

\begin{abstract}
In the context of accelerating housing development for low-income people (MBR), the government makes simplification efforts in simplifying licensing for low-income housing development. To expedite this, the government issued Government Regulation Number 64 of 2016 concerning Low-Income Community Housing Development, then to accelerate its implementation in the regions, it is regulated in Minister of Home Affairs Regulation Number 55 of 2017 concerning Implementation of Licensing and Non-Permitting Housing Development for Low-Income Communities (MBR) in the Region. This study aims to determine government policies related to the implementation of MBR housing development and to determine the performance of the Minister of Home Affairs Regulation Number 55 of 2017 concerning the Implementation of Licensing and Non-Licensing of Housing Development for Low-Income Communities (MBR) in the Regions, especially in the city of Palembang.
\end{abstract}

Keywords: Licensing Policy, MBR Housing.

\section{A. INTRODUCTION}

The housing sector is a complex problem, which is not merely a physical aspect of building a house but is related to an inclusive industry in its procurement, such as land, the building materials industry, the environment and socio-economic aspects of community culture, to build elements of people's lives harmonious (Benfer \& Gold, 2017). Therefore, housing development as a whole cannot be separated from the overall development of settlements and is an essential part of building an efficient and productive community life (Average, 2019).

The management of housing affairs, including the arrangement of slum settlements, is a political choice of the local government and results from a formulation with the domain of political bureaucracy. The public choice perspective is usually carried out with a pluralist approach pattern based on fundamental assumptions about organized society's basic wants and needs (Efendi, 2014). Tuner and Turner \& Hulme (1997:122) call it: The public choice perspective has a kinship with the pluralist approach in its basic assumption about political society being composed of organized interests so that it requires sharpening in terms of elections that are useful for community (Dahab, Flasche \& Checchi, 2020). An approach with attention to this aspect is essential because a policy formulation and implementation is an element that cannot be separated conceptually (Dye, 1992). 
According to the PUPR Ministry, there are 11 million households that do not have proper housing in Indonesia (Fallahi, 2017). This figure consists of 7.6 million homeownership backlogs and 2.3 million uninhabitable houses. There is still a lot of work to be done and problems to be solved by the government going forward (Grumbach, Vargas, Fleisher \& Schmidt, 2017). In general, there are 3 (three) problems faced by MBR house developers in urban areas, namely the problem of limited land, regional regulations, and financing (Hadjon, 1993).

The provision of land, especially in big cities such as Jakarta, Medan, Surabaya, Makassar, Palembang, and other cities, is challenging to build MBR houses. According to Hutapea \& Suwandono (2014), the low purchasing power of low-income people makes it difficult to access homes offered by the market and the lack of available land (Larson, Looby, Frost \& Story, 2017). On the other hand, the government has no opportunities to help the community access land. This is where the role of local governments in supporting housing policies for low-income households becomes important (Hutapea \& Suwandono, 2015).

The implementation of government affairs policies in the housing and settlement areas refers to Law Number 23 of 2014 concerning Regional Government in Appendix D (Table 1). Government affairs in the housing and settlement areas cover 5 (five) sub-government affairs, namely; 1) Housing, 2) Settlement Areas, 3) Housing and Slum Settlement Areas, 4) Public Infrastructure, Facilities, and Utilities (PSU); and 5) Certification, Qualification, Classification, and Registration of Housing and Settlement Areas (Mehmood, Rowther, Kobusinge \& Hyder, 2018).

Implementing the housing and settlement area policy in Indonesia underwent significant changes related to the government affairs division as stipulated in the previous law (Law Number 32 of 2004 concerning Regional Government). The division of concurrent government affairs between the province and the regency/municipality, even though the government affairs are the same, will be seen from the scale or scope of the government affairs (O'Shaughnessy, Barbose, Wiser \& Dorghouth, 2021). Although provincial and district/city areas have their nonhierarchical government affairs, there will still be a relationship between the central government, restricted regions, and district/city areas in their implementation by referring to norms, standards, procedures, and criteria (NSPK) made by the Central Government.

With the issuance of Law Number 23 of 2014 concerning Regional Government, regions are given the authority according to Article 17 (1). Parts have the right to determine Regional policies to carry out Government Affairs, which are under the control of the Regions, to formulate policies, one of which is policies regarding government affairs in the housing sector. And residential areas (Prasojo, 2009). The construction of housing and settlements, if carried out systemically, will directly contribute to the improvement of welfare and poverty alleviation (Riant, 2004). This is because housing development can encourage regional and regional economic growth, support socio-cultural development and make a real contribution to increasing employment opportunities, economic growth, alleviating poverty, and 
improving welfare (Satori \& Komariah, 2009). Therefore, the construction of housing and settlements must be based on a comprehensive and integrated policy, strategy and program, and activities so that apart from being able to fulfill the people's fundamental rights.

\section{B. METHOD}

This research is a type of descriptive research conducted to determine the value of variables, either one or more variables, without comparing or connecting one variable to another, using research methods with a qualitative approach to primary data and secondary data (Sugiyono, 2006). Data collection in this study was carried out by collecting secondary data from relevant Regional Apparatus Organizations in the form of Reports on the Implementation and Achievement of Service Minimum Service Standards, Strategic Plans, Renja, annual reports, Lakip, and library research to enrich research in the form of books, journals. Research results and other information that supports this research.

\section{RESULT AND DISCUSSION}

\section{Housing and Residential Area Policy}

The basis for formulating RPJMN IV policies for 2020-2025 is the fulfillment of housing needs equipped with supporting infrastructure and facilities for all communities supported by a sustainable, efficient, and accountable long-term housing financing system to create a city without slums. While SDGs 11, the goal is to ensure access to decent, safe, affordable housing and essential services and manage slum areas.

The challenges faced by the government in making Housing Infrastructure for the community are (1) Millennials Generation Housing Needs (population in 2019; + 81 million people, (2) The large number of backlogs of 7.6 million houses and 2.3 million RTLH, and (3) Improving the quality of housing and settlements. The next challenge faced by the government in making housing policies is the backlog of houses and uninhabitable houses, which are still very large with details as follows, BPS data in 2015 was 11.4 million backlogs and 3,4 million RTLH backlog. Meanwhile, the One Million Houses Program (PSR) in 2015-2019 is the construction of new houses (PRB) of 3,772,160 units and the Improvement of the Quality of Uninhabitable Houses (PKRTLH) of 1,020,158 units. The housing deficit in 2020 is 7.63 million housing backlogs and 2.38 million uninhabitable housing backlogs (RTL). It can be broken down that the housing deficit in 2020 is as follows: (a) +6.63 million MBR Non-Fixed Income backlog, (b) + 1.1 million Fixed Income MBR House backlog, and (3) + 2.38 million Non-Fixed Income MBR RTLH backlog.

The targets of the 2015 - 2019 Strategic Plan for the provision of housing based on the 2015-2019 RPJMN targets are as follows: 1) Construction of Flats for MBR equipped with supporting PSUs of 550,000 units; 2) Construction of Special Houses in post-disaster/conflict, maritime/fishing areas, and state borders equipped with 50,000 units of supporting PSU; 3) Facilitation of Stimulant Assistance for New 
Self-Help Construction of 250,000 units; 4) Facilitation of Stimulant Assistance to Improve the Quality of Self-help Houses as much as 1,500,000 units; and 5) Construction of livable houses, which include livable treaded public houses which were facilitated through the assistance of 676,950 units of PSU Public Houses.

Table 1 Target for the Strategic Plan for the Provision of Housing for 2015-2019

\begin{tabular}{|c|c|c|c|c|c|}
\hline & Flats & $\begin{array}{c}\text { Special } \\
\text { House }\end{array}$ & $\begin{array}{c}\text { Self Help } \\
\text { House }\end{array}$ & $\begin{array}{c}\text { PK Self- } \\
\text { help House }\end{array}$ & $\begin{array}{c}\text { Common } \\
\text { Home PSU }\end{array}$ \\
\hline Target & 550,000 & 50,000 & 250,000 & $1,500,000$ & 676,950 \\
\hline $\mathbf{2 0 1 5}$ & 10,497 & 6,402 & 20,756 & 61,489 & 29,956 \\
\hline $\mathbf{2 0 1 6}$ & 7,740 & 6,042 & 1,007 & 96,881 & 26,884 \\
\hline $\mathbf{2 0 1 7}$ & 13,251 & 5,037 & 2,000 & 110,732 & 17,218 \\
\hline $\mathbf{2 0 1 8}$ & 11,670 & 4,525 & 5,999 & 195,305 & 30,406 \\
\hline $\mathbf{2 0 1 9}$ & 5,634 & 1,954 & 5,453 & 236,234 & 15,148 \\
\hline Achievements & $\mathbf{4 8 , 7 9 2}$ & $\mathbf{2 3 , 9 6 0}$ & $\mathbf{3 5 , 2 1 5}$ & $\mathbf{7 0 0 , 6 4 1}$ & $\mathbf{1 1 9 , 6 1 2}$ \\
\hline
\end{tabular}

Source: LAKIP, Directorate General of Housing Provision, Ministry of PUPR in 2019

In general, the problem of housing implementation is the affordability of the community to decent housing, both in terms of buying new houses that are suitable for habitation and building homes independently, and there are still many people who live in uninhabitable dwellings. The imbalance between supply and demand causes the problem of affordability. This inequality occurs due to various factors, including the high rate of population growth and increased urbanization in urban areas, which are not balanced with the provision of decent housing (Sinharoy, Pittluck \& Clasen, 2019). From the demand side, the main problem is the low ability of the community, especially the Low-Income Community (MBR), to buy decent houses or building them independently (Soehino, 1984). The number of homes built by developers for MBR is still limited, not commensurate with the community's needs. To ensure the affordability of MBR in decent housing, the government has provided housing financing assistance, although it has not been running optimally.

Developers who are partners with the government in meeting housing needs are generally more interested in developing luxury and medium-sized homes. For houses built by developers to be affordable for low-income people (MBR), developers must be guided by the Joint Decree between the Minister of Home Affairs, the Minister of Public Works. The State Minister of Public Housing, Number 648-381/1992, 739/KPTS/ 1992 and 09/KPTS/1992 concerning Guidelines for the Development of Housing and Settlements with a Balanced Residential Environment regulates the provisions on the comparison between the construction of luxury houses, construction of medium-sized dwellings and building of simple houses is 1 : 3: 6, usually will also choose locations in suburban areas. Therefore, currently on the outskirts of Palembang City, which borders Ogan Ilir Regency, Ogan Komering Ilir Regency, and Banyuasin Regency, the construction and growth of land houses/landed houses is taking place rapidly, especially for medium and straightforward types of homes. 
Table 2 Number of Palembang City House Backlog Facilities in 2019

\begin{tabular}{|c|c|c|c|c|c|}
\hline No & Districts & Village & $\begin{array}{c}\text { Number } \\
\text { of } \\
\text { Houses }\end{array}$ & $\begin{array}{l}\text { Number } \\
\text { of Family } \\
\text { Cards in } \\
2019\end{array}$ & $\begin{array}{c}\text { Home } \\
\text { Backlog in } \\
2019\end{array}$ \\
\hline \multirow{4}{*}{1} & \multirow{4}{*}{$\begin{array}{l}\text { Alang-Alang } \\
\text { Lebar }\end{array}$} & Srijaya & 3386 & 6253 & 2867 \\
\hline & & Karya Baru & 4649 & 7753 & 3104 \\
\hline & & Alang-Alang Lebar & 1430 & 3153 & 1723 \\
\hline & & Talang Kelapa & 6868 & 12133 & 5265 \\
\hline \multirow{6}{*}{2} & \multirow{6}{*}{ Bukit Kecil } & Talang Semut & 719 & 1541 & 822 \\
\hline & & 22 Ilir & 238 & 832 & 594 \\
\hline & & 19 Ilir & 362 & 848 & 486 \\
\hline & & 23 Ilir & 972 & 933 & +39 \\
\hline & & 26 Ilir & 1587 & 3287 & 1700 \\
\hline & & 24 Ilir & 3367 & 4566 & 1199 \\
\hline \multirow{5}{*}{3} & \multirow{5}{*}{ Gandus } & Pulokerto & 2863 & 3916 & 1053 \\
\hline & & Gandus & 3278 & 5483 & 2205 \\
\hline & & Karang Jaya & 2176 & 3383 & 1207 \\
\hline & & Karang Anyar & 1871 & 4067 & 2196 \\
\hline & & 36 Ilir & 1750 & 3618 & 1868 \\
\hline \multirow{6}{*}{4} & \multirow{6}{*}{ Ilir Barat Satu } & Bukit Lama & 4221 & 11880 & 7659 \\
\hline & & 26 Ilir D I & 694 & 1661 & 967 \\
\hline & & Look Pakjo & 3657 & 8937 & 5280 \\
\hline & & $\begin{array}{l}\text { Demang Lebar } \\
\text { Daun }\end{array}$ & 3507 & 6761 & 3254 \\
\hline & & Bukit Baru & 2233 & 6362 & 4129 \\
\hline & & Siring Agung & 2343 & 6164 & 3821 \\
\hline \multirow{7}{*}{5} & \multirow{7}{*}{ Ilir Barat Dua } & 35 Ilir & 1622 & 3453 & 1831 \\
\hline & & 32 Ilir & 1364 & 4329 & 2965 \\
\hline & & 30 Ilir & 2375 & 6066 & 3691 \\
\hline & & Kemang Manis & 831 & 2552 & 1721 \\
\hline & & 29 Ilir & 1053 & 647 & +406 \\
\hline & & 28 Ilir & 235 & 926 & 691 \\
\hline & & 27 Ilir & 396 & 2066 & 1670 \\
\hline \multirow{7}{*}{6} & \multirow{7}{*}{ Ilir Timur Satu } & 18 Ilir & 372 & 813 & 441 \\
\hline & & 16 Ilir & 372 & 323 & +49 \\
\hline & & 13 Ilir & 393 & 855 & 462 \\
\hline & & 14 Ilir & 547 & 980 & 433 \\
\hline & & 15 Ilir & 977 & 1495 & 518 \\
\hline & & 17 Ilir & 1107 & 1219 & 112 \\
\hline & & Kepandean Baru & 475 & 1267 & 792 \\
\hline
\end{tabular}




\begin{tabular}{|c|c|c|c|c|c|}
\hline No & Districts & Village & $\begin{array}{c}\text { Number } \\
\text { of } \\
\text { Houses }\end{array}$ & $\begin{array}{c}\text { Number } \\
\text { of Family } \\
\text { Cards in } \\
2019\end{array}$ & $\begin{array}{c}\text { Home } \\
\text { Backlog in } \\
2019\end{array}$ \\
\hline & & 20 Ilir I & 3153 & 4059 & 906 \\
\hline & & Sungai Pangeran & 2792 & 2960 & 168 \\
\hline & & 20 Ilir III & 1011 & 2544 & 1533 \\
\hline & & 20 Ilir IV & 1323 & 4557 & 3234 \\
\hline \multirow{6}{*}{7} & \multirow{6}{*}{ Ilir Timur Dua } & Lawang Kidul & 1765 & 3089 & 1324 \\
\hline & & 3 Ilir & 2569 & 4345 & 1776 \\
\hline & & 1 Ilir & 978 & 1899 & 921 \\
\hline & & Sungai Buah & 3700 & 3993 & 293 \\
\hline & & 2 Ilir & 3970 & 5759 & 1789 \\
\hline & & 5 Ilir & 2845 & 2384 & +461 \\
\hline \multirow{6}{*}{8} & \multirow{6}{*}{ Ilir Timur Tiga } & 10 Ilir & 441 & 6826 & 6385 \\
\hline & & 11 Ilir & 915 & 4257 & 3342 \\
\hline & & Kuto Batu & 1951 & 1224 & +727 \\
\hline & & Duku & 4149 & 1124 & +3025 \\
\hline & & 9 Ilir & 2546 & 4415 & 1869 \\
\hline & & 8 Ilir & 4210 & 5135 & 925 \\
\hline \multirow{5}{*}{9} & \multirow{5}{*}{ Jakabaring } & $15 \mathrm{Ulu}$ & 2849 & 7275 & 4426 \\
\hline & & Tuan Kentang & 1790 & 2754 & 964 \\
\hline & & 8 Ulu & 1733 & 2932 & 1199 \\
\hline & & Silaberanti & 3482 & 4817 & 1335 \\
\hline & & 9/10 Ulu & 2366 & 3066 & 700 \\
\hline \multirow{5}{*}{10} & \multirow{5}{*}{ Kalidoni } & Sei Lais & 2719 & 4115 & 1396 \\
\hline & & Sei Selina & 5667 & 7917 & 2250 \\
\hline & & Sei Selayur & 3210 & 6197 & 2987 \\
\hline & & Kalidoni & 3516 & 8780 & 5264 \\
\hline & & Bukit Sangkal & 5053 & 8730 & 3677 \\
\hline \multirow{6}{*}{11} & \multirow{6}{*}{ Kemuning } & Sekip Jaya & 2858 & 4571 & 1713 \\
\hline & & Pahlawan & 2157 & 3567 & 1410 \\
\hline & & 20 Ilir II & 2656 & 4655 & 1999 \\
\hline & & Pipa Reja & 2460 & 5327 & 2867 \\
\hline & & Talang Aman & 1642 & 3605 & 1963 \\
\hline & & Ario Kemuning & 1976 & 3003 & 1027 \\
\hline \multirow{5}{*}{12} & \multirow{5}{*}{ Kertapati } & Karya Jaya & 2077 & 3317 & 1240 \\
\hline & & Keramasan & 2907 & 3690 & 783 \\
\hline & & Kemang Agung & 3379 & 6851 & 3472 \\
\hline & & Kemas Rindo & 3190 & 5136 & 1946 \\
\hline & & Ogan Baru & 3969 & 6160 & 2191 \\
\hline
\end{tabular}




\begin{tabular}{|c|c|c|c|c|c|}
\hline No & Districts & Village & $\begin{array}{c}\text { Number } \\
\text { of } \\
\text { Houses }\end{array}$ & $\begin{array}{c}\text { Number } \\
\text { of Family } \\
\text { Cards in } \\
2019\end{array}$ & $\begin{array}{c}\text { Home } \\
\text { Backlog in } \\
2019\end{array}$ \\
\hline & & Kertapati & 2046 & 3058 & 1012 \\
\hline \multirow{7}{*}{13} & \multirow{7}{*}{ Plaju } & Plaju Darat & 5821 & 5531 & +290 \\
\hline & & Talang Putri & 1977 & 5105 & 3128 \\
\hline & & Compete & 1374 & 835 & +539 \\
\hline & & Plaju Ilir & 1884 & 4407 & 2523 \\
\hline & & Talang Bubuk & 1364 & 2851 & 1487 \\
\hline & & Plaju Ulu & 3222 & 6547 & 3325 \\
\hline & & Bagus Kuning & 1839 & 3230 & 1391 \\
\hline \multirow{4}{*}{14} & \multirow{4}{*}{ Sako } & Sukamaju & 5325 & 8558 & 3233 \\
\hline & & Silang & 5631 & 6543 & 912 \\
\hline & & Sako & 7448 & 12255 & 4807 \\
\hline & & Sako Baru & 1741 & 3489 & 1748 \\
\hline \multirow{5}{*}{15} & \multirow{5}{*}{$\begin{array}{c}\text { Seberang Ulu } \\
\text { Satu }\end{array}$} & $1 \mathrm{Ulu}$ & 1554 & 2445 & 891 \\
\hline & & $2 \mathrm{Ulu}$ & 1384 & 2281 & 897 \\
\hline & & 3-4 Ulu & 2967 & 4471 & 1504 \\
\hline & & 5 Ulu & 3230 & 8332 & 5102 \\
\hline & & 7 Ulu & 2328 & 4428 & 2100 \\
\hline \multirow{7}{*}{16} & \multirow{7}{*}{$\begin{array}{c}\text { Seberang Ulu } \\
\text { Dua }\end{array}$} & $11 \mathrm{Ulu}$ & 1229 & 4924 & 3695 \\
\hline & & 12 Ulu & 791 & 8263 & 7472 \\
\hline & & 13 Ulu & 2104 & 5435 & 3331 \\
\hline & & $14 \mathrm{Ulu}$ & 2244 & 3876 & 1632 \\
\hline & & Tangga Takat & 2899 & 3476 & 577 \\
\hline & & $16 \mathrm{Ulu}$ & 4292 & 1736 & +2556 \\
\hline & & Sentosa & 3021 & 2164 & +857 \\
\hline \multirow{4}{*}{17} & \multirow{4}{*}{$\begin{array}{l}\text { Sematang } \\
\text { Borang }\end{array}$} & Lebung Gajah & 5239 & 4220 & +1019 \\
\hline & & Srimulya & 1346 & 2060 & 714 \\
\hline & & Suka Mulya & 943 & 6648 & 5705 \\
\hline & & Karya Mulya & 1717 & 1508 & +209 \\
\hline \multirow{7}{*}{18} & \multirow{7}{*}{ Sukarami } & Sukabangun & 3654 & 3450 & +204 \\
\hline & & Sukajaya & 9264 & 8760 & +504 \\
\hline & & Sukarami & 3478 & 4450 & 972 \\
\hline & & Kebun Bunga & 6460 & 6547 & 87 \\
\hline & & Talang Betutu & 1029 & 4320 & 3291 \\
\hline & & Sukodadi & 4096 & 4210 & 114 \\
\hline & & Talang Jambe & 1814 & 4252 & 2438 \\
\hline \multicolumn{3}{|c|}{ Amount } & 271,019 & 460,222 & 189,203 \\
\hline
\end{tabular}

Source: Processed Data, 2020 
Based on the table above, it can be seen that 14 urban villages do not need to add housing units because the current number of housing units can meet the needs of houses or more in 2019. Based on the RT RW of Palembang City, the fulfillment of housing and settlement needs for the short, medium. Long-term needs to be carried out with the development of large-scale settlements through the Ready-to-Build Area (Kasiba) and the Ready-to-Build Environment (Lisiba), independent of the Palembang City Regional Spatial Plan.

\section{Implementation of Housing Development Permits for Low-Income Communities in Palembang City}

The policy for accelerating and facilitating housing development permits for MBR has not been fully implemented consistently in the regions (Subica, Douglas, Kepple \& Grills, 2018). This can be seen from the number of Regional Governments that compile regulations related to the ease of licensing as a follow-up to Government Regulation Number 64 of 2016 concerning MBR Housing Development and the mandate of Article 10 of the Minister of Home Affairs Regulation Number 55 of 2017 concerning Implementation of Licensing and Non-licensing of Housing Development for Low-Income Communities in the Region that the Region establishes a Regional Head Regulation in the context of facilitating the implementation of Housing development Licensing and Non-licensing for MBR. Until 2019, the Regional Governments identified as having issued Perkada concerning the ease of licensing for MBR housing development are 4 (four) Regencies/Cities, namely Prabumulih City, Muara Enim Regency, Sleman Regency, and Pontianak City. Then as many as 3 (three) Provinces have issued a Governor's Decree regarding the Acceleration of MBR Housing Development, namely South Sulawesi Province, North Sumatra Province, and South Sumatra Province. Meanwhile, there are 3 (three) Regencies/Cities currently ratifying the Perkada, namely Tomohon City, Manado City, and Lubuk Linggau City.

Furthermore, 5 (five) Regencies/Cities have provided SOPs for Simplifying Housing Licensing, namely Surabaya City, Balikpapan City, South Tangerang City, and Muara Enim Sumedang Regency, and Tangerang Regency. Not many regions have implemented this policy, hindering developers, not least developers who build houses for MBR, in building housing. Another problem related to the implementation of this policy is that the synergy between policies and stakeholders in the housing and settlement areas is not strong enough even though the Housing and Settlement Area Working Group (Pokja PKP) has been formed to facilitate the resolution of problems with licensing barriers in the housing sector.

The South Sumatra Provincial Government is following up on the Economic Policy Package XIII of the Jokowi Government and the mandate of the Minister of Home Affairs Number 55 of 2017 concerning the Implementation of Licensing and Non-Licensing of Housing Development for Low-Income Communities in the Regions, issuing Circular Letter No. 056/Se/Perkim/2019 concerning Ease of Licensing for Subsidized Housing Development for people in South Sumatra. The 
circular letter is intended to provide direction and guidance to Regents/Mayors throughout South Sumatra, heads of regional apparatus within the South Sumatra Provincial Government, Banking Leaders, GM PT. providing licensing and nonlicensing in the construction of low-income housing (MBR).

The Office of Investment and One-Stop Integrated Services (DPMPTSP) of Palembang City is part of the Regional Government of South Sumatra Province. Palembang Mayor Regulation Number 55 of 2015 concerning the delegation of authority in the Licensing Sector to the Head of the Investment and One-Stop Service Office. The Office of Investment and One-Stop Integrated Services (DPMPTSP) is a supporting element for the mayor's duties in licensing services based on the authority possessed by the City Government following the provisions of different laws and regulations. Since the inauguration of the Palembang City PTSP Mall on November 27, 2020, the PAN-RB Minister, the Palembang City Investment and OneStop Integrated Service (DPMPTSP), has served 337 Licensing Services in 28 Agencies. To provide ease of licensing and non-licensing of MBR Housing in DPMPTSP Palembang City has practically been implemented but has not been regulated in special regulations (Perda and Perwali) in one form of law related to the overall authority of DPMPTSP but is still separated in several Perda / Perwali, among others; Regional Regulation Number 1 of 2018 (related to the ease of Environmental Management Permits) and Mayor of Palembang Regulation Number 7 of 2020 (related to Dispensation for IMB Retribution Fees).

Table 3 Differences in the Division of Government Affairs Housing Sector Related to MBR

\begin{tabular}{|c|c|c|}
\hline Government & Law Number 1 the Year 2011 & Law Number 23 the Year \\
2014
\end{tabular}




\begin{tabular}{|l|l|c|}
\hline Government & Law Number 1 the Year 2011 & $\begin{array}{c}\text { Law Number 23 the Year } \\
2014\end{array}$ \\
\hline & $\begin{array}{l}\text { - Facilitating the provision of } \\
\text { housing and settlement areas } \\
\text { for the community, especially } \\
\text { for MBR }\end{array}$ & \\
\hline
\end{tabular}

Source: Processed Data, 2020

Law Number 23 of 2014 states that the affairs of providing housing for MBR are only the Central Government's authority, thus limiting the Regional Government to support the realization of development for housing for MBR and contributing to reducing the housing backlog and RTL. This also impacts not achieving the target due to the burden given to the Central Government to build houses for MBR, which is quite large but is not balanced with the availability of the budget.

Table 4 Division of Government Affairs in the Housing and Settlement Areas

\begin{tabular}{|c|c|c|c|c|}
\hline No. & $\begin{array}{c}\text { Sub- } \\
\text { Affiliation }\end{array}$ & Central government & Province & $\begin{array}{c}\text { Regency area/ } \\
\text { City }\end{array}$ \\
\hline 1. & Housing & 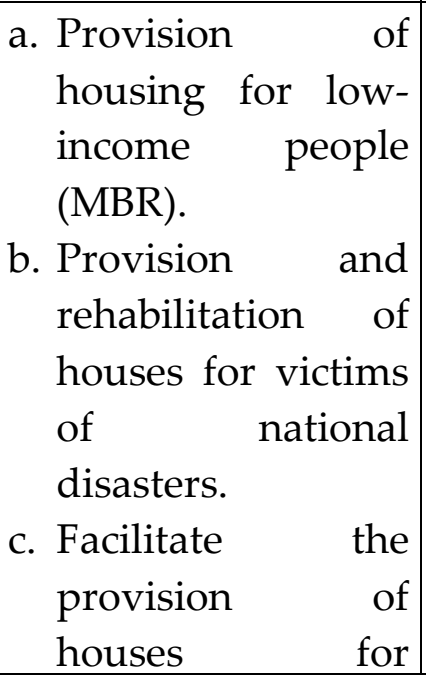 & $\begin{array}{l}\text { a. Provision and } \\
\text { rehabilitation } \\
\text { of provincial } \\
\text { disaster } \\
\text { victims' houses. } \\
\text { b. Facilitating the } \\
\text { provision of } \\
\text { houses for } \\
\text { communities } \\
\text { affected by the } \\
\text { relocation of } \\
\text { the Provincial }\end{array}$ & $\begin{array}{l}\text { a. Provision and } \\
\text { rehabilitation of } \\
\text { houses for } \\
\text { disaster victims } \\
\text { in districts/cities. } \\
\text { b. Facilitating the } \\
\text { provision of } \\
\text { houses for } \\
\text { communities } \\
\text { affected by the } \\
\text { relocation of the } \\
\text { district/city }\end{array}$ \\
\hline
\end{tabular}

Source: Processed Data, 2020

\section{Regulatory Ambiguity in MBR Housing Development}

The government has issued Government Regulation Number 64 of 2016 concerning MBR Housing and Development, its implementation in the Regency / City area is still not fully as expected. Whereas following Government Regulation Number 64 of 2016, the government has included the provision of licensing facilities in the form of ratification of site plans and issuance of IMB for developers who build MBR houses, especially landed houses with a land area of 0.5-5 hectares (ha), which is then added in the form of ease of requirements, services, and acceleration of licensing completion time.

In addition, the permits that are allowed to be merged are MBR proposals related to land claims that are not disputed, and space utilization permits with a 
checking process or suitability of plans, ratification of site plans with environmental management statements or recommendations for firefighters and others (Suteedi, 2015). With the instructions from the president in granting accelerated permits, for this reason, it is expected that the time for processing land rights from owners can be accelerated to a maximum of three days. For the future, maybe even in a matter of hours (Turner \& Humle, 1997).

Apart from accelerating licensing for MBR housing development, the government is also thinking about the housing deficit (housing backlog). A simple definition of the housing backlog is the gap between housing needs and the number of existing houses. The main problem of the housing backlog is the number of homes built and the number of decent housing needs, especially for low-income people.

Article 2 paragraph (1) reads that the construction of MBR housing is carried out for a land area of not more than 5 (five) hectares and at least 0.5 (zero points five) hectares and is located in 1 (one) location designated for the construction of landed houses. Then the Ministry of Home Affairs issued Regulation of the Minister of Home Affairs Number 55 of 2017 concerning Implementation of Licensing and NonLicensing of Housing Development for Low-Income Communities in the Region Article 5 (1) Legal Entities that carry out housing development for MBR in the regions are carried out for a land area of not more than 5 (five) hectares and at least 0.5 (zero points five) hectares, and located in 1 (one) location designated for the construction of a landed house.

If the two articles of the statutory regulations above are met, then the need for MBR housing cannot be fulfilled because the statute limits landed houses. Meanwhile, the city of Palembang has relatively no land allotted for the construction of MBR housing for landed homes, except for land for flats. The land is a classic problem that is often encountered in the provision of housing. Land problems, in general, are high prices and limited availability in urban areas (Winarno, 2002). Providing land with adequate space and worth to be used as a location for house construction, especially in urban areas, is a tricky thing. This led to the emergence of land scarcity problems, which resulted in land prices rising and house prices becoming more expensive and unaffordable for MBR.

\section{CONCLUSION}

In the implementation of housing licensing for low-income communities in Palembang City, there are several things, namely, first, optimization of Housing and Settlement Area Policies Based on the RPJMD is stated in one of the missions of the Palembang City RPJMD 2018-2023 to overcome the backlog in Palembang City to achieve national development goals. Second, in the context of accelerating the Implementation of Housing Development Licensing for Low-Income Communities in the City of Palembang, the Governor of South Sumatra has issued Circular Letter No. 056/Se/Perkim/2019 concerning Ease of Licensing for Subsidized Housing Development for Communities in South Sumatra to provide direction to the Regency/City in the province of South Sumatra. Third, several factors hinder the 
implementation of licensing for low-income housing development, namely the overlapping authority between Law Number 1 of 2011 concerning Housing and Settlement Areas and Law Number 23 of 2014.

\section{REFERENCES}

1. Average, C. (2019). Low-income housing problems and low-income housing solutions: opportunities and challenges in Bulawayo. Journal of Housing and the Built Environment, 34(3), 927-938.

2. Benfer, E. A., \& Gold, A. E. (2017). There's no place like home: reshaping community interventions and policies to eliminate environmental hazards and improve population health for low-income and minority communities. Harv. L $\mathcal{E}$ Poly Rev. Online S1, 11.

3. Dahab, M., Van Zandvoort, K., Flasche, S., Warsame, A., Ratnayake, R., Favas, C., ... \& Checchi, F. (2020). COVID-19 control in low-income settings and displaced populations: what can realistically be done?. Conflict and health, 14(1), $1-6$.

4. Dye, T. R. (1992). Understanding Public Policy. New Jersey: Englewood Cliffs.

5. Efendi, L. (2004). Pokok-Pokok Hukum Administrasi Negara. Malang: Bayumedia Sakti Group.

6. Fallahi, B. (2017). Evaluation of National Policy toward Providing Low-Cost Housing in Malaysia. International Journal of Social Sciences, 6(1), 9-19.

7. Government Regulation Number 64 of 2016 concerning Development and Housing for Low-Income Communities

8. Grumbach, K., Vargas, R. A., Fleisher, P., Aragón, T. J., Chung, L., Chawla, C., ... \& Schmidt, L. A. (2017). Achieving health equity through community engagement in translating evidence to policy: the San Francisco Health Improvement Partnership, 2010-2016.

9. Hadjon, P. M. (1993). Pengantar Hukum Perizinan. Surabaya: Yuridika.

10. Hutapea, H., \& Suwandono, D. (2015). Perencanaan Pembangunan Perumahan Baru dan Strategi Pengadaan Tanah Bagi Masyarakat Berpenghasilan Rendah di Kecamatan Banyumanik. Ruang, 2(4), 371-380.

11. Larson, N., Looby, A. A., Frost, N., Nanney, M. S., \& Story, M. (2017). What can be learned from existing investigations of weight-related practices and policies with the potential to impact disparities in US child-care settings? A narrative review and call for surveillance and evaluation efforts. Journal of the Academy of Nutrition and Dietetics, 117(10), 1554-1577.

12. Law Number 1 of 2011 concerning Housing and Settlement Areas.

13. Law Number 23 of 2014 concerning Regional Government.

14. Mehmood, A., Rowther, A. A., Kobusingye, O., \& Hyder, A. A. (2018). Assessment of pre-hospital emergency medical services in low-income settings using a health systems approach. International journal of emergency medicine, 11(1), $1-10$. 
15. Minister of Home Affairs Regulation Number 55 of 2017 concerning the Implementation of Licensing and Non-Licensing of Housing Development for Low-Income Communities.

16. O'Shaughnessy, E., Barbose, G., Wiser, R., Forrester, S., \& Darghouth, N. (2021). The impact of policies and business models on income equity in rooftop solar adoption. Nature Energy, 6(1), 84-91.

17. Prasojo, E. (2009). Reformasi Kedua: Melanjutkan Estafet Reformasi. Jakarta: Penerbit Salemba.

18. Riant, N. D. (2004). Kebijakan Publik, Formulasi, Implementasi, dan Evaluasi, penerbit PT. Elex Media Komputindo kelompok Gramedia, Jakarta.

19. Satori, D. A., \& Komariah, A. (2009). Metodologi penelitian kualitatif. Bandung: Alfabeta, 22.

20. Sinharoy, S. S., Pittluck, R., \& Clasen, T. (2019). Review of drivers and barriers of water and sanitation policies for informal urban settlements in low-income and middle-income countries. Utilities Policy, 60, 100957.

21. Soehino. (1984). Asas-asas Hukum Tata Pemerintahan. Yogyakarta: Liberty.

22. Subica, A. M., Douglas, J. A., Kepple, N. J., Villanueva, S., \& Grills, C. T. (2018). The geography of crime and violence surrounding tobacco shops, medical marijuana dispensaries, and off-sale alcohol outlets in a large, urban low-income community of color. Preventive medicine, 108, 8-16.

23. Sugiyono, D. P. (2009). Metode Penelitian Administrasi Dilengkapi Dengan Metode R\&D. Revisi. Alfabeta.

24. Suteedi, A. (2015). Hukum Perizinan: Dalam Sektor Pelayanan Publik. Jakarta: Sinar Grafika.

25. Turner, M., \& Hulme, D. (1997). Governance, Administration, and Development: Making the state work. Macmillan International Higher Education.

26. Winarno, B. (2002). Teori dan Proses Kebijakan Publik. Yogyakarta: Media Pressindo. 